\title{
GAMBARAN KADAR KOLESTEROL TOTAL PADA PECANDU KOPI KECAMATAN POASIA KOTA KENDARI
}

\author{
Overview the Total Cholesterol Levels Of Coffee Addicts \\ in Poasia Subdistrict, City Of Kendari
}

\author{
Satya Darmayani ${ }^{1}$, Anita Rosanty ${ }^{1}$, Dian Rahmayani $\mathbf{A}^{\mathbf{1}}$ \\ ${ }^{1}$ Jurusan Analis Kesehatan Politeknik Kesehatan Kemenkes Kendari
}

\begin{abstract}
One of the effects of coffee consumption that still questionable is the increase of total cholesterol levels. The content of cafestol in coffee beans could be expected to block the process of $\beta$-oxidation of cholesterol that increases cholesterol levels in the blood. This study aimed to describe the normal total cholesterol levels and high total cholesterol levels in coffee addicts in the working area of Puskesmas Poasia, Subdistrict of Poasia. The research sample amounted 38 people taken by purposive sampling. The results showed that the total cholesterol levels test in coffee addicts obtained as many as 14 people (36.84\%) with normal total cholesterol levels and as many as 24 people $(63.16 \%)$ had a high total cholesterol level, but from 24 people of the coffee addicts, there are 4 of them in young age and allowed the possibility of an increase in cholesterol levels become faster due to genetic, lifestyle and unhealthy diet. It concluded that of the 38 people of coffee addicts who tested the cholesterol levels, the number of coffee addicts with high total cholesterol levels more than coffee addicts with normal total cholesterol levels. Therefore, it suggested people to reduce consumption of coffee, especially those for coffee addicts.
\end{abstract}

Keywords: Coffee, cafestol, cholesterol

\section{PENDAHULUAN}

Pada bulan Februari 2016 ekspor kopi dunia mencapai $9.210 .000 \quad$ karung dibandingkan bulan Februari 2015 yaitu 9.050.000 karung. Ekspor kopi terus meningkat tiap tahunnya di seluruh dunia. Ekspor kopi dari Bulan Oktober hingga Februari 2016 telah meningkat sebesar 2,0\% (International Coffea Organization, 2016) (Kanisius, 1988). Kopi merupakan salah satu minuman yang paling banyak dikonsumsi di dunia. Sejak beberapa abad yang lalu, kopi telah menjadi bahan perdagangan, karena kopi dapat diolah sebagai penyegar badan dan pikiran (Sri, Kiptiyah and Semaoen, 2009).

Konsumsi kopi masyarakat Indonesia per kapita pada tahun 2013 sekitar 1,03 kilogram per tahun dan Indonesia pada tahun 2013 merupakan negara penghasil kopi ketiga terbesar di dunia setelah Brazil dan Vietnam (AEKI, 2014). Dengan melihat perkembangan permintaan kopi tersebut dapat diketahui bahwa pertumbuhan permintaan kopi di Indonesia sangat besar tiap tahunnya, dan tanpa disadari kopi telah menjadi kebutuhan utama bagi masyarakat mulai dari kalangan remaja hingga orang dewasa yang menikmati kopi sebagai minuman untuk memulai hari maupun sebagai penahan rasa kantuk.

Kopi mengandung lebih dari 500 senyawa kimia lainnya, salah satu diantaranya adalah kafestol. Kafestol adalah konstituen utama dari reaksi penyabunan minyak kopi yaitu sekitar $0,2-0,6 \%$ dari bobot kopi. Zat ini 
bersifat anti kanker dan zat yang dapat mencegah kerusakan hati. Perbedaan hasil diperoleh bila zat kafestol ini dikonsumsi dalam jumlah tinggi. Kafestol yang dikonsumsi dalam jumlah berlebihan dapat meningkatkan asam lemak bebas dan kolesterol dalam darah yang dapat menimbulkan endapan-endapan lemak dan plak yang menempel dan menyumbat dinding arteri (Insan and Kurniawaty, 2016). Banyak penelitian melaporkan bahwa kopi dapat meningkatkan kadar kolesterol darah, serum homosistein, meningkatkan denyut jantung dan tekanan darah, yang dapat menjadi faktor risiko penting meningkatnya penyakit jantung koroner (Choi, Jang and Cho, 2010), (Freedman et al., 2012)' (Naidoo et al., 2011). Kafestol meningkatkan kadar kolesterol dengan cara menghambat mekanisme beta oksidasi sehingga mencegah pemecahan kolesterol menjadi energi.

Setiap orang memiliki kolesterol di dalam darahnya, $80 \%$ diproduksi oleh tubuh sendiri dan $20 \%$ berasal dari makanan dan minuman yang dikonsumsi (Ann, 2011), (Waloya, Rimbawan and Andarwulan, 2013). Kolesterol yang yang berlebihan di dalam darah akan mudah melekat pada dinding sebelah dalam pembuluh darah. Kadar kolesterol dalam tubuh pada dasarnya dapat dikontrol dengan pola hidup yang sehat serta menghindari jenis makanan atau minuman yang dapat meningkatkan kadar kolesterol contohnya teh dan kopi (Achtiar and Sofiana, 2014).
Di Sulawesi Tenggara, tingkat produksi kopi terus meningkat tiap tahunnya. Berdasarkan data Badan Pusat Statistik Sulawesi Tenggara, pada tahun 2014 produksi kopi mencapai 6.729 ton, produksi kopi mengalami kenaikan yang semula hanya 3.685 ton pada tahun 2013. Data menunjukkan produksi kopi berbanding lurus dengan tingkat konsumsi kopi. Dengan demikian dapat disimpulkan bahwa tingkat konsumsi kopi di Sulawesi Tenggara dari tahun ke tahun semakin meningkat (Tenggara, 2015).

Di Kota Kendari khususnya Kecamatan Poasia merupakan salah satu kecamatan yang terdiri dari 4 kelurahan, yaitu Kelurahan Rahandouna, Kelurahan Anduonohu, Kelurahan Anggoeya, dan Kelurahan Matabubu. Penelitian ini dilakukan berfokus di Kecamatan Poasia karena tingkat konsumsi kopi masyarakat di Kecamatan Poasia sangat tinggi. Hal ini disebabkan karena banyaknya masyarakat yang bekerja pada industri rumahan seperti industri kayu, logam, anyaman, dan lain-lain, serta pekerjaan dengan aktifitas fisik yang berat, yang kemudian membutuhkan kopi sebagai penahan kantuk dan penyegar badan saat bekerja, dan berdasarkan observasi yang dilakukan langsung di Kecamatan Poasia dengan melakukan kuisioner sebanyak 400 kuisioner kepada masyarakat yang tinggal di Kecamatan Poasia didapatkan 254 orang yang mengonsumsi kopi secara berlebihan.

Telah dilakukan penelitian sebelumnya tentang Pengaruh Pemberian Kopi terhadap 
Kadar Kolesterol dan Trigliserida pada Tikus Wistar (Rattus novergiccus) oleh Millah dkk., tahun 2014 dimana hasilnya didapatkan kadar kolesterol dan trigliserida yang normal pada Tikus Wistar yang tidak diberi kopi sedangkan pada Tikus Wistar yang diberi kopi didapatkan peningkatan kadar kolesterol dan trigliserida (Zindany, Kadri and Almurdi, 2014).

Berdasarkan uraian di atas peneliti tertarik untuk melakukan penelitian tentang gambaran kadar kolesterol total pada pecandu kopi di wilayah kerja Puskesmas Poasia Kecamatan Poasia Kota Kendari Provinsi Sulawesi Tenggara.

\section{METODE}

\section{Jenis Penelitian}

Jenis Penelitian yang digunakan adalah penelitian deskriptif, yaitu untuk memperoleh gambaran hasil pemeriksaan kadar kolesterol total pada pecandu kopi di wilayah kerja Puskesmas Poasia Kecamatan Poasia Kota Kendari Provinsi Sulawesi Tenggara.

\section{Lokasi dan Waktu Penelitian}

Penelitian ini berlokasi di wilayah kerja Puskesmas Poasia yaitu di Kecamatan Poasia yang terdiri dari Kelurahan Rahandouna, Kelurahan Anduonohu, Kelurahan Anggoeya, dan Kelurahan Matabubu. Penelitian ini dilaksanakan pada bulan Juni 2016.

\section{Populasi dan Sampel}

Populasi dalam penelitian ini adalah seluruh masyarakat di Kecamatan Poasia yang mengonsumsi kopi secara berlebihan sebanyak 254 orang, yang terdiri dari 67 orang di Kelurahan Rahandouna, 84 orang di Kelurahan Anduonohu, 47 orang di Kelurahan Anggoeya, dan 56 orang di Kelurahan Matabubu. Jumlah populasi diperoleh dari 400 kuisioner yang dibagikan kepada masyarakat di Kecamatan Poasia. Besar sampel yang diambil dalam penelitian ini yaitu $15 \%$ karena jumlah populasi > 100, maka besar sampel dalam penelitian ini yaitu 38 sampel dan teknik pengambilan sampel yang digunakan yaitu purposive sampling.

\section{Pengumpulan Data}

Jenis data yang dikumpulkan dalam penelitian ini meliputi kriteria inklusi yakni : usia diatas 25 tahun, konsumsi kopi lebih dari 2 gelas perhari, dan konsumsi kopi lebih dari 5 tahun. Sedangkan kriteria eksklusi yang diteliti : perempuan, sedang mengonsumsi obat yang dapat menurunkan kadar kolesterol, mengalami Obesitas. Data dikumpulkan melalui wawancara menggunakan kuisioner. Pemeriksaan kadar kolesterol total menggunakan alat autoklik (Nesco), alat pengukur kadar kolesterol (Nesco), strip kolesterol (Nesco), kapas alkohol 70\%, lanset, mikropipet volume $10 \mathrm{ul}$, serta tips kuning. Dikategorikan kolesterol normal apabila nilai kolesterol total dalam darah sebesar 154-231 $\mathrm{mg} / \mathrm{dl}$ dan dikatakan kolesterol tinggi apabila kolesterol total dalam darah $>231 \mathrm{mg} / \mathrm{dl}$. 
HASIL

Distribusi responden berdasarkan kelompok umur di wilayah kerja puskesmas Poasia kecamatan Poasia kota Kendari Provinsi Sulawesi Tenggara tahun 2016 menunjukkan bahwa pecandu kopi dengan kelompok umur 26-35 tahun sebanyak 17 orang dengan persentase $44,74 \%$, kelompok umur 36-45 tahun sebanyak 11 orang dengan persentase 28,95\%, kelompok umur 46-55 tahun sebanyak 6 orang dengan persentase
15,79\%, kelompok umur 56-65 tahun sebanyak 2 orang dengan persentase 5,26\%, dan kelompok umur > 56 tahun sebanyak 2 orang dengan persentase $5,26 \%$. Hal tersebut menunjukkan bahwa pecandu kopi dengan kelompok umur 26-35 tahun merupakan kelompok umur dengan persentase tertinggi, dan kelompok umur $>65$ merupakan kelompok umur dengan persentase terendah (Tabel 1).

Tabel 1. Distribusi Responden Berdasarkan Kelompok Umur di Wilayah Kerja Puskesmas Poasia Kecamatan Poasia Kota Kendari Provinsi Sulawesi Tenggara

\begin{tabular}{ccc}
\hline Kelompok Umur & Frekuensi (f) & Persentase (\%) \\
\hline $26-35$ & 17 & 44,74 \\
$36-45$ & 11 & 28,95 \\
$46-55$ & 6 & 15,79 \\
$56-65$ & 2 & 5,26 \\
$>65$ & 2 & 5,26 \\
Jumlah & 38 & 100 \\
\hline
\end{tabular}

Berdasarkan kelompok pekerjaan, distribusi responden di wilayah kerja Puskesmas Poasia Kecamatan Poasia Kota Kendari Provinsi Sulawesi Tenggara Tahun 2016 menunjukkan bahwa pecandu kopi dengan pekerjaan sebagai Pegawai Negeri Sipil sebanyak 1 orang dengan persentase $2,63 \%$, Wiraswasta sebanyak 22 orang dengan persentase $57,89 \%$, Swasta sebanyak 10 orang dengan persentase 26,32\%, dan Petani sebanyak 5 dengan persentase $13,16 \%$. Hal ini menunjukkan bahwa pecandu kopi dengan pekerjaan sebagai wiraswasta merupakan pekerjaan dengan persentase tertinggi, dan pekerjaan sebagai pegawai negeri sipil merupakan pekerjaan dengan persentase terendah (Tabel 2). 
Tabel 2. Distribusi Responden Berdasarkan Kelompok Pekerjaan di Wilayah Kerja Puskesmas Poasia Kecamatan Poasia Kota Kendari Provinsi Sulawesi Tenggara

\begin{tabular}{ccc}
\hline Pekerjaan & Frekuensi (f) & Persentase (\%) \\
\hline Pegawai Negeri Sipil & 1 & 2,63 \\
Wiraswasta & 22 & 57,89 \\
Swasta & 10 & 26,32 \\
Petani & 5 & 13,16 \\
Jumlah & 38 & 100 \\
\hline
\end{tabular}

Distribusi responden berdasarkan indeks massa tubuh di wilayah kerja Puskesmas Poasia Kecamatan Poasia Kota Kendari Provinsi Sulawesi Tenggara Tahun 2016 menunjukkan bahwa pecandu kopi dengan indeks massa tubuh yang kurus sebanyak 3 orang dengan persentase $7,89 \%$, pecandu kopi dengan indeks massa tubuh yang normal sebanyak 21 orang dengan persentase $55,27 \%$,

Tabel 3. Distribusi Responden Berdasarkan Indeks Massa Tubuh di Wilayah Kerja Puskesmas Poasia Kecamatan Poasia Kota Kendari Provinsi Sulawesi Tenggara

\begin{tabular}{ccc}
\hline Indeks Massa Tubuh & Frekuensi (f) & Persentase (\%) \\
\hline Kurus & 3 & 7,89 \\
Normal & 21 & 55,27 \\
Gemuk & 14 & 36,84 \\
Jumlah & 38 & 100 \\
\hline
\end{tabular}

Hasil pemeriksaan kadar kolesterol total di wilayah kerja Puskesmas Poasia Kecamatan Poasia Kota Kendari Provinsi Sulawesi Tenggara Tahun 2016 menunjukkan bahwa pecandu kopi yang memiliki kadar kolesterol total yang normal yaitu 14 orang dengan persentase sebanyak $36,84 \%$, dan pecandu dan pecandu kopi dengan indeks massa tubuh yang gemuk sebanyak 14 orang dengan persentase $36,84 \%$. Hal ini menunjukkan bahwa indeks massa tubuh yang normal merupakan indeks massa tubuh dengan persentase tertinggi, dan indeks massa tubuh yang kurus merupakan indeks massa tubuh dengan persentase terendah (Tabel 3). kopi yang memiliki kadar kolesterol total yang tinggi yaitu 24 orang dengan persentase sebanyak $63,16 \%$. Hal ini menunjukkan bahwa pecandu kopi yang memiliki kadar kolsterol total yang tinggi memiliki persentase lebih tinggi (Tabel 4). 
Tabel 4. Hasil Pemeriksaan Kadar Kolesterol Total di Wilayah Kerja Puskesmas Poasia Kecamatan Poasia Kota Kendari Provinsi Sulawesi Tenggara

\begin{tabular}{ccc}
\hline Hasil Pemeriksaan & Frekuensi (f) & Persentase (\%) \\
\hline Normal & 14 & 36,84 \\
Tinggi & 24 & 63,16 \\
Jumlah & 38 & 100 \\
\hline
\end{tabular}

\section{PEMBAHASAN}

Pada penelitian yang dilakukan di wilayah kerja Puskesmas Poasia Kecamatan Poasia tahun 2016, tentang gambaran kadar kolesterol total pada pecandu kopi dengan menggunakan metode Strip diperoleh hasil penelitian yaitu dari 38 pecandu kopi yang diperiksa sebanyak $24(63,16 \%)$ pecandu kopi yang telah mengkonsumsi kopi lebih dari 5 tahun memiliki kadar kolesterol total yang tinggi. Hal ini sesuai dengan teori yang menyatakan bahwa konsumsi kopi dalam jangka waktu panjang dapat menyebabkan peningkatan kadar kolesterol total dalam tubuh, hal ini dikarenakan kopi mengandung kafestol yang mengganggu kestabilan kerja tubuh dan mempengaruhi metabolisme kolesterol di dalam tubuh (Graha, 2010). Beberapa penelitian menyimpulkan adanya hubungan positif antara konsumsi kopi dengan peningkatan pada lipid serum. Salah satu penelitian yang dilakukan terhadap 17 orang sehat yang kemudian diberikan diet 6 cangkir kopi selama 4 minggu menunjukkan peningkatan kadar kolesterol total (TC) sebesar $22 \mathrm{mg} / \mathrm{dl}$ (Arnesen, Forde and Thelle, 1984). Penelitian lain menunjukkan hasil serupa, terjadi peningkatan kadar kolesterol total pada kelompok dengan konsumsi kopi 3 cangkir atau lebih per hari dan peningkatan trigliserida (TG) dengan konsumsi kopi 5 cangkir atau lebih per hari (Green and Jucha, 1986).

Peningkatan kadar kolesterol total dalam darah banyak terjadi pada pecandu kopi yang memiliki usia di atas 36 tahun. Pada seorang pecandu kopi dengan usia di atas 36 tahun, laju metabolisme dalam tubuh melambat, dan semakin melemahnya organorgan dalam tubuh sehingga dapat menyebabkan kemampuan atau aktivitas reseptor kolesterol menjadi berkurang dan peningkatan kadar kolesterol total dalam darah semakin cepat (Wahyani, 2012). Peningkatan kadar kolesterol total dalam darah juga disebabkan karena aktivitas tubuh yang kurang sementara tingkat konsumsi kopi terus meningkat yang disebabkan oleh pekerjaan yang membutuhkan kopi untuk menahan rasa kantuk, seperti pekerja pada industri rumahan yang berada di Kecamatan Poasia (Margarita et al., 2013). Sebagaimana diketahui bahwa Kecamatan Poasia merupakan daerah yan memiliki banyak industri rumahan, seperti industri kayu, keramik, kain tenun, dan lainlain. 
Dari 24 orang pecandu kopi yang memiliki kadar koleterol tinggi ditemukan 4 $(16,67 \%)$ diantaranya pecandu kopi yang berusia kurang dari 36 tahun, hal ini dapat disebabkan oleh kadar kolesterol total meningkat lebih cepat. Nilawati (2008) menyatakan bahwa peningkatan kadar kolesterol total menjadi lebih cepat pada usia muda yang dapat disebabkan oleh pola hidup yang tidak baik, seperti merokok, genetik serta pola makan (Nilawati et al., 2008). Yang dimana merokok akan meningkatkan kecenderungan sel-sel darah untuk menggumpal di dalam pembuluh darah dan melekat pada lapisan dalam pembuluh darah, yang karena rokok tersebut dapat menurunkan kadar High Density Lipoprotein (HDL). Dimana HDL berfungsi untuk membersihkan pembuluh darah dari kolesterol Low Density Lipoprotein (LDL) yang berlebihan dalam darah (Muliyana and Thaha, 2013)' (Iz and Maindi, 2015).

Kirana (2011) juga menyatakan peningkatan kolesterol total pada usia muda menjadi lebih cepat juga dapat disebabkan oleh faktor genetik. Yakni seseorang yang memiliki riwayat keturunan kolesterol tinggi akan cepat mengalami kenaikan kolesterol dalam darahnya setelah mengkonsumsi makanan dan minuman yang dapat meningkatkan kadar kolesterol. Selain itu, seseorang dengan pola makan yang tidak baik dan banyak mengkonsumsi makanan yang dapat memicu peningkatan kadar kolesterol akan memiliki kadar kolesterol total yang tinggi (Oktomalioputri, Darwin and Decroli, 2016).

Peningkatan kolesterol total juga banyak terjadi pada pecandu kopi yang memiliki indeks massa tubuh yang gemuk dan normal. Dari 14 (36,84\%) pecandu kopi yang memiliki indeks massa tubuh yang gemuk 9 (64,29\%) diantaranya memiliki kadar kolesterol total yang tinggi. Dan dari $21(55,27 \%)$ pecandu kopi yang memiliki indeks massa tubuh yang normal $14(66,67 \%)$ diantaranya memiliki kadar kolesterol total yang tinggi. Nurjanah (2015) menyatakan bahwa hubungan kuat terjadi antara perubahan serum kolesterol dengan berat badan sejak dewasa muda hingga usia pertengahan. Terjadinya penambahan berat badan pada usia dewasa kebanyakan antara usia 20-50 tahun. Pada waktu yang bersamaan, serum kolesterol juga meningkat. Setiap peningkatan $1 \mathrm{~kg} / \mathrm{m}^{2}$ indeks massa tubuh berhubungan dengan peningkatan kolesterol total sebesar $7,7 \mathrm{mg} / \mathrm{dl}$ dan penurunan tingkat HDL sebesar $0,8 \mathrm{mg} / \mathrm{dl}$ (Nurjanah and Roosita, 2015).

Hasil penelitian ini juga menunjukkan bahwa dari 38 pecandu kopi yang diperiksa saat penelitian diperoleh $14(36,84 \%)$ pecandu kopi yang memiliki kadar kolesterol total yang normal. Nadimin (2015) menyatakan bahwa seseorang dengan aktivitas yang berat dapat membantu menurunkan kadar kolesterol, aktivitas tubuh memberikan pengaruh yang baik pada profil lipid plasma. Konsentrasi kolesterol total diturunkan sebagai akibat menurunnya LDL dan trigliserida, sedangkan 
HDL meningkat (Nadimin, Ayumar and Fajarwati, 2015). Demikian pula dengan hasil penelitian Anwar (2004) aktivitas fisik dapat meningkatkan kadar HDL dalam darah dan memperbaiki kolateral koroner sehingga menurunkan kadar kolesterol total. Selain itu aktivitas fisik dapat menurunkan berat badan sehingga lemak yang berlebihan berkurang bersama-sama dengan menurunnya LDL kolesterol. Beberapa penelitian juga melaporkan bahwa aktivitas tubuh yang berat dapat meningkatkan kadar HDL, menurunkan kadar trigliserida dan LDL serta menurunkan resistensi insulin (Anwar, 2004).

Kadar kolesterol total normal pada pecandu kopi dapat disebabkan pula oleh pola makan yang baik, seperti banyak mengkonsumsi makanan atau minuman yang dapat membuat kadar kolesterol dalam darah menurun. Kirana (2011) menyatakan bahwa mengatur pola makan, dan mengurangi makanan yang mengandung lemak tinggi akan menurunkan kadar kolesterol dalam darah, seperti mengkonsumsi makanan yang mengandung omega-3. Omega-3 dapat mencegah peningkatan kadar kolesterol dan menurunkan kadar LDL dalam darah dan meningkatkan kadar HDL, serta menurunkan resiko terjadinya pembekuan pada pembuluh darah (Sari, Azrimaidaliza and Purnakarya, 2010).

\section{KESIMPULAN DAN SARAN}

Kadar kolesterol total pada pecandu kopi di wilayah kerja Puskesmas Poasia Kecamatan Poasia dari 38 orang pecandu kopi yang telah mengkonsumsi kopi lebih dari 5 tahun diperoleh hasil pecandu kopi yang memiliki kadar kolesterol total tinggi lebih banyak dengan persentase $63,16 \%$ dibanding pecandu kopi dengan kadar kolesterol total normal dengan persentase $36,84 \%$.

Kepada masyarakat diharapkan agar mengurangi mengonsumsi kopi terkhusus bagi pecandu kopi. Bagi peneliti lain, hendaknya mengembangkan penelitian terkait dengan kadar kolesterol pada pecandu kopi khususnya LDL dan trigliserida, memperhatikan pola makan pecandu kopi, pola hidup pecandu kopi serta melihat dari segi pendidikan pecandu kopi yang akan diteliti.

\section{DAFTAR PUSTAKA}

Achtiar, Y. A. and Sofiana, K. D. (2014) 'Efek Preventif Ekstrak Etanol Kopi Robusta (Coffea Canephora ) Terhadap Peningkatan Kadar Kolesterol Total Tikus Jantan Galur Wistar yang Diinduksi Kuning Telur ( The Preventive Effect of Robusta Coffee ( Coffea canephora ) Ethanolic Extracts Against the ', e-Jurnal Pustaka Kesehatan, 2(3), pp. 1-5.

AEKI (2014) Konsumsi Kopi Domestik. Jakarta.

Ann, L. K. (2011) Awas, Diaskol. Cetakan Pe. Yogyakarta: Syura Media Utama.

Anwar (2004) Faktor Risiko Penyakit Jantung Koroner. Universitas Sumatera Utara.

Arnesen, E., Forde, O. H. and Thelle, D. S. (1984) 'Coffee and Serum Cholesterol', British Medical Journal, 288, p. 1960.

Choi, E., Jang, J. and Cho, Y. (2010) 'Coffee Intake Can Promote Activity of Antioxidant Enzymes with Increasing MDA Level and Decreasing HDLCholesterol in Physically Trained Rats', Nutrition Research and Practice, 4(4), pp. 283-289. doi: 10.4162/nrp.2010.4.4.283.

Freedman, N. D. et al. (2012) 'Association of Coffee Drinking with Total and CauseSpecific Mortality', The New England Journal of Medicine. 
Graha, C. K. (2010) Question and Answer Kolesterol. Jakarta: Elex Media Komputindo.

Green, M. S. and Jucha, E. (1986) 'Association of Serum Lipids with Coffee , Consumption in Free-Living Subjects Tea , and Egg Consumption in FreeLiving Subjects', Journal of Epidemiology and Community Health, 40, pp. 324-329.

Insan, A. N. M. and Kurniawaty, E. (2016) 'Pengaruh Kopi Terhadap Hipertensi The Effect of Coffee on Hypertension', Majority, 5(2).

Iz, A. and Maindi, E. J. (2015) 'Behavior Smoking as Modification Effects of Type 2 DM Events', Jurnal MKMI, pp. 118124.

Kanisius, A. A. (1988) Budidaya Tanaman Kopi. Yogyakarta: Kanisius.

Margarita, Y. et al. (2013) 'Kadar Kolesterol Total dan Tekanan Darah Orang Dewasa Indonesia', Jurnal Kesehatan Masyarakat Nasional, 8(2), pp. 79-84.

Muliyana, D. and Thaha, I. L. M. (2013) 'Factors Related to Smoking Habits of Hasanuddin University Students Makassar', Jurnal MKMI, pp. 109-119.

Nadimin, Ayumar and Fajarwati (2015) 'Obesitas Pada Orang Dewasa Anggota Keluarga Miskin di Kecamatan Lembang Kabupaten Pinrang', Jurnal MKMI, pp. 9-15.

Naidoo, N. et al. (2011) 'Cholesterol- Raising Diterpenes in Types of Coffee Commonly Consumed in Singapore, Indonesia and India and Associations with Blood Lipids: A Survey and Cross Sectional Study', Nutrition Journal. BioMed Central Ltd, 10(1), pp. 1-10. doi: 10.1186/1475-2891-10-48.
Nilawati, S. et al. (2008) Care Yourself, Kolesterol. Cetakan I. Edited by S. Kusumawati. Jakarta: Penebar Plus.

Nurjanah, F. and Roosita, K. (2015) 'Gaya Hidup dan Kejadian Sindrom Metabolik Pada Karyawan Laki-laki Berstatus Gizi Obes di PT. Indocement Citeureup', Jurnal Gizi Pangan, 10(1), pp. 17-24.

Oktomalioputri, B., Darwin, E. and Decroli, E. (2016) 'Pengaruh Lama Pemberian Diet Tinggi Kolesterol terhadap Kadar LDL dan TGF- B Serum Tikus Putih ( Rattus novergicus ) strain Wistar', Jurnal Kesehatan Andalas, 5(1), pp. 267-273.

Sari, D. M., Azrimaidaliza and Purnakarya, I. (2010) 'Faktor Resiko Kolesterol Total Pasien Penyakit Jantung Koroner di Rumah Sakit Achmad Mochtar Bukit Tinggi', Jurnal Kesehatan Masyarakat, 4(2), pp. 77-81.

Sri, W., Kiptiyah, S. . and Semaoen, M. I. (2009) 'An Analysis of the Coffee Export of Indonesia', Wacana, 12(1).

Tenggara, B. P. S. P. S. (2015) Sulawesi

Tenggara Dalam Angka. Kendari.

Wahyani, A. D. (2012) Perbedaan Kadar Trigliserida Serum Tikus Srague Dawley Pada Pemberian Kopi Robusta Filter Dan Tanpa Filter. Universitas Diponegoro Semarang.

Waloya, T., Rimbawan and Andarwulan, N. (2013) 'Hubungan Antara Konsumsi Pangan dan Aktivitas Fisik dengan Kadar Kolesterol Darah Pria dan Wanita Dewasa di Bogor', Jurnal Gizi dan Pangan, 8(1), pp. 9-16.

Zindany, M. F., Kadri, H. and Almurdi (2014) 'Pengaruh Pemberian Kopi terhadap Kadar Kolesterol dan Trigliserida pada Tikus Wistar ( Rattus novergiccus )', Jurnal Kesehatan Andalas, 3(1), pp. 1-5. 